\title{
Conjuring the Mysteries of Slavery: Voodoo, Fetishism, and Stereotype in Ishmael Reed's Flight to Canada
}

\section{Citation}

Carpio, Glenda R. 2005. Conjuring the mysteries of slavery: Voodoo, fetishism, and stereotype in Ishmael Reed's Flight to Canada. American Literature 77(3): 563-589.

\section{Published Version}

http://dx.doi.org/10.1215/00029831-77-3-563

\section{Permanent link}

http://nrs.harvard.edu/urn-3:HUL.InstRepos:3209546

\section{Terms of Use}

This article was downloaded from Harvard University's DASH repository, and is made available under the terms and conditions applicable to Other Posted Material, as set forth at http:// nrs.harvard.edu/urn-3:HUL.InstRepos:dash.current.terms-of-use\#LAA

\section{Share Your Story}

The Harvard community has made this article openly available.

Please share how this access benefits you. Submit a story.

Accessibility 
Glenda R. Conjuring the Mysteries of Slavery:

Carpio

Voodoo, Fetishism, and Stereotype in

Ishmael Reed's Flight to Canada

In a vibrant proliferation since the mid-1960s, fictional texts have grappled with the characteristic omissions, gaps, and distortions in the record of New World slavery. ${ }^{1}$ Often referred to as neo-slave narratives, some of these texts assume polemical or revisionist approaches in order to correct the historical record, while others focus on the obscure and unarticulated facets of slavery in an imaginative recuperation of the past. ${ }^{2}$ In Flight to Canada (1976), Ishmael Reed adopts both strategies. But he also explores the legacy of slavery in the present; to this end, he proposes an alternative lexicon for historical reconstruction. ${ }^{3}$ Drawing on the social, political, and artistic practices of Voodoo, Reed transfigures nontextual forms of remembrance from the cultural legacy of the African diaspora to extend the limits of the discourse on slavery. His aesthetic in Flight to Canada also incorporates aspects of postmodernism to show the connections between chattel slavery's reification of people and bodies and the fetishistic notions of race and sexuality it has produced.

Reed draws from Voodoo-specifically from its New World version, also known as hoodoo or conjure-because, as a cultural practice transported by enslaved Africans across the Middle Passage, Voodoo maintains an unwritten record of slavery and the diaspora. Etymologically in the language of the African Fons, Voodoo means introspection (vo) into the unknown (dou or $d u$ ); culturally, it is a form of ancestor worship in which the souls of the dead-known as loa or mystères-are evoked and made manifest through ritual. ${ }^{4}$ In the New World, especially in Haiti, Voodoo rituals recall and restage the history of cultural dislocation and enslavement. Reed recognizes that Voodoo has University Press. 
served as an unwritten text through which various communities in the New World, including the American South, have kept alive collective memories of dispossession and survival. Steering clear of nostalgia or essentialism, Reed draws on Voodoo's social and political history to incorporate its metaphysical, epistemological, and aesthetic visions. ${ }^{5}$ For Voodoo practitioners, history is functional, experiential, nontextual, and nonlogocentric. What would it mean, Reed asks, to transfigure Voodoo's terminology into a critical memory of slavery? ${ }^{6}$

Voodoo practitioners do not regard the past as a set of events neatly sealed off from the now; instead, the past informs and intermingles with everyday reality. Ancestors, or loa, are worshipped not because they have supernatural powers but because, as the dead, they have knowledge of the past and experience with the mysteries and unseen forces that lie beyond the concrete reality of the living (hence, they are literally known as mystères). Voodoo devotees worship ancestors for pragmatic reasons through experiential means. They conjure them to ask for favors, for example, that will improve the public good. ${ }^{7}$ The loa, according to Joan Dayan, are said to reenter the world by "taking possession" of practitioners in what is called a crise de loa - the moment in which the soul of an ancestor mounts the body of the devotee and attains a physical presence. As embodied entities, the ancestors walk among the living, intermingling the past with the present and abstract realities with the material world. ${ }^{8}$

Reed's use of Voodoo challenges the most pervasive notions about the practice. "[T]o most readers," notes Maya Deren, "[Voodoo's concept of] religious possession is not only unfamiliar, but carries exotic and sensational overtones" ("DH," 16). Dayan suggests that for nonpractitioners, this unfamiliarity with "the demands and expectations" of the loa can turn the concept of possession into an abstract principle; Voodoo then attains an aura of inaccessibility that some choose to translate into negative terms ("V," 41). Rather than a potent form of knowing and being, Voodoo can become synonymous with superstition, evil, black magic, and zombies. Voodoo's negative reputation as an occult practice is exacerbated by the fact that a percentage of its practitioners use it as a form of sorcery. That is why the houngan, or Voodoo ritual leader, distinguishes himself from the boco, who practices conjuring for witchcraft and uses it to create "zombies." 9

Reed, however, takes what appear to be the strangest aspects of 
Voodoo and explores them beyond their aura of superstition. Zombification as practice and concept, for example, provides Reed with metaphorical ways of remembering slavery. Reed's views could be said to coincide with those of Dayan, who quotes Edward Rochester in Jean Rhys's Wide Sargasso Sea, when Rochester finds a definition of zombie during his stay in the Caribbean: "A zombi is a dead person who seems to be alive or a living person who is dead. [It] can also be the spirit of a place." Dayan adds that a zombie, "[b]orn out of the experience of slavery and the sea passage from Africa to the New World, ... tells the story of colonization: the reduction of human into thing for the ends of capital." ${ }^{10}$ For Haitians, zombies are "those soulless husks deprived of freedom and forced to work as slaves, [who] remain the ultimate sign of loss and dispossession" ("V," 55). ${ }^{11} \mathrm{Be}-$ cause Voodoo practitioners understand zombification as a "fantastic process of reification," Dayan suggests that their emphasis on possession should be understood as recognition of the material realities of reification and as sabotage against the powers of dispossession. ${ }^{12}$

Reed transliterates Voodoo's notion of zombification and belief in spirit possession in order to signify on the limited grid of representation that chattel slavery produced about the people that were called masters, mistresses, and slaves. On one hand, Reed uses his writing as a boco would his witchcraft, breathing life into stereotypes of resistance, submission, dominance, benevolence, brutality, and forbearance; by conjuring them as a group of embodied ideas, he creates zombie-like characters that represent humanity divested of its soul. On the other hand, he uses his writing like a houngan would his conjuring powers, calling into being the ancestors or spirits - the historical as well as imaginative loa-of slavery. ${ }^{13}$ The word loa comes from the French word lois, meaning law, and refers to Voodoo's conception of the laws of creation. ${ }^{14}$ But as Sämi Ludwig argues, what Reed means by loa are not only the historical ancestors from our past but also "the ideas that prestructure our experiences as well as our interpretations, the principles [or laws] that govern our minds and our souls and the forces and institutions representing them."15

Through his conjure, Reed illustrates how slavery's stereotypesas representations that embody fixed ideas, ideological fictions, and psychic fantasies - are inert in essence but alive in their effects. Like zombies, they are emblems of a "fantastic process of reification" that 
through his fiction assume the semblance of life. In Flight to Canada, zombie characters are those that substitute stereotyped behavior for critical and conscious action. By contrast, characters that are able to repossess and manipulate stereotypes in order to realize personal and collective freedom figure as ancestors whose legacy Reed honors. The two kinds of characters are made to "walk" in each other's midst, often assuming similar manifestations and thus forcing the reader to wrestle with the hermeneutical challenges that the legacy of slavery presents.

Flight to Canada concerns the plight of three fugitive slaves. Reed conjures two of them as figures of resistance: Raven Quickskill evokes the radical slave lecturer and author epitomized by Frederick Douglass, and "40s" personifies the stereotype of the militant revolutionary most often associated with Nat Turner. The third fugitive slave, Stray Leechfield, suggests the more ambivalent figure of the minstrel performer. The narrative also relates the stories of the master class and of the "house slaves" that do not escape. While the latter are embodied in Uncle Robin and Mammy Barracuda, figures that recall two central icons of forbearance and domesticity-Uncle Tom and the mammy - the master class is provocatively presented in a polarizing logic. Arthur Swille, the "owner" of all the slaves, is draconian, sadomasochistic, and set against Abraham Lincoln, whose benevolent and heroic role as the Great Emancipator is exaggerated and parodied. While Reed employs most of these figures to unleash the power of zombie-like stereotypes, he also employs some of them-Raven and Robin, in particular - to evoke the spirits of slave ancestors.

Transforming Voodoo's ritualistic practices into literary techniques, Reed is able to represent the "zombies" of slavery as unique entities whose effects we perceive through their actions. As a religion of the poor and uneducated (most devotees are illiterate), Voodoo maintains its historical memory through rituals that include dance, music, incantations, oral stories, and, most prominently, vévés, or ground drawings. ${ }^{16}$ Reed interprets and improvises these aspects of Voodoo practice, using elements from popular culture to create his own particularized version of a literary Voodoo ritual. He borrows from the content and style of visual art forms-especially comic strips, film, and photography - to create animated caricatures of slavery's zombies and the historical ideologies surrounding them. At the same time, he interlocks diverse time frames to show how the violence, lusts, and lures of the past-as these are embodied in stereotypes-manifest 
themselves across time. Flight to Canada, then, operates within a fictional space that merges the past (antebellum and Civil War America) with the novel's present (the years after the Civil Rights movement), both of which intersect with our own present moment of reading.

Reed conjures the zombie-like qualities of slavery's stereotypes through an aggrandizing enterprise that relies on parody and highlights the distortions that such images promote, pushing them beyond their overtly familiar places in our imagination and exposing them as fetishistic forces. The fetish, Christian Metz argues, springs from a fear of what is perceived as absent in another (such as the absence of a phallus in women). The construction of the fetish, adds Metz, entails making the evidence one sees for this apparent lack "retrospectively unseen by a disavowal of the perception, and in stopping the look, once and for all, on an object ... which was ... near, just prior to, the place of the terrifying absence." ${ }^{17}$ The stereotype, like the fetish, is a distorted image of all that seems "terrifyingly" different about another; it takes the place of actual understanding and acknowledgment of a common humanity. In the absence of that recognition, the fetishistic image or stereotype, at once generalized and specific, takes its place.

Reed defetishizes the stereotype by aggrandizing its distortions. In his hands, it comes alive, as if newly produced, and overwhelms the reader's senses. He makes it bigger, louder, more grotesque, and more insufferable than it already is in order to arrest our attention and induce us to explore the fears and fantasies that the stereotype, like the fetish, seeks to keep at bay. As Reed parades the host of distortions produced by the institution of slavery, he creates a comic atmosphere with a cathartic and deconstructive effect, which allows him to conjure the difficult, hidden ideas and emotions that the stereotypes at once suggest and mask. Reed thus conjures mysteries in a dual sense: while he uses certain narrative techniques to evoke the ancestors or mystères of slavery, he aggrandizes the human distortions slavery produced to conjure the thoughts and emotions that the stereotype, as an obscuring phenomenon, renders mysterious.

At one level, Flight to Canada is literally structured as a Voodoo ritual. It begins with the chanting of ancestors' names, proceeds toward the crise de loa or possession stage-which is characterized by the novel's dynamic interplay between the past and the present-and ends when the novel fixes its focus on a more contemporary time frame. Raven Quickskill opens the narrative with a poem he's written, 
and then, in a section set off from the rest of the novel by italics, he provides a short meditation on the limits of the literature and historiography of slavery as well as the modes that are used to interpret them. The narrative next switches quickly to the voice of an omniscient narrator who relates most of the plot and ends with another firstperson meditation, also set off by italics, by Uncle Robin, who reflects on the narrative's events. Raven's introduction is simultaneously a historiographic meditation and a literary incantation of the names of slavery's ancestors, an invocation that calls them into presence: "Lincoln. Harriet Beecher Stowe. Douglass. Jeff Davis and Lee . . . Stray Leechfield. Robin and Judy . . Mammy Barracuda." 18 While some of these names are actual American ancestors, many are fantasies of our imagination.

Reed establishes the shift from Raven's incantations to the possession stage or crise de loa of the novel through a change of narrative perspective. As Ashraf Rushdy argues, the fact that the novel begins with Raven's first-person meditation and then abruptly switches into the third-person account of an omniscient narrator suggests that the structure of Flight to Canada is Reed's enactment of Voodoo's most basic practice, the act of spirit possession..$^{19}$ Shortly before the narrative adopts the third-person voice, Raven asks: "Do the lords still talk? Do the lords still walk? Are they writing this book?" $(F C, 10)$. Thereafter Raven's individual voice becomes "possessed" by a third-person narrator who connects the multiple manifestations of the loa and the zombies that Reed evokes. The identity of this third-person narrative voice, in turn, attains the qualities of a specific Voodoo loa named Guede who manifests himself in the realms of eroticism and death and who permeates the text as a primary presence. ${ }^{20}$ "Guede is here," writes Raven as the novel begins. "Guede is in New Orleans. Guede got people to write parodies and minstrel shows about Harriet" $(F C, 9)$. The only other time we come back "here," and to "New Orleans," is at the end of the novel when we are told that "Raven is back" and the omniscient narrator signs off:

"12:01 A.M.

Tamanaca Hotel, Room 127

Fat Tuesday

March 2, 1976

New Orleans" $(F C, 179)$ 
When Raven comes “back," Guede's presence ends and the narrative returns to the present time of the novel (1976).

The allusion to New Orleans at the end of Raven's "possession" also returns us to a place known for its retention of conjure and, by implication, connects the wider world of the African diaspora (figured through Voodoo) to the events of the novel. On one hand, Reed draws out this connection through the novel's structure, which literally transliterates Voodoo's ritualistic patterns. On the other hand, he uses Voodoo's metaphysical and epistemological aspects to create a memory of slavery that is functional rather than nostalgic, experiential rather than passive, and nonlogocentric rather than strictly rational or simply mimetic. Since Voodoo belief and practice are neither centered on a single deity nor bound to a written text, Voodoo devotees locate meaning in flux, stressing flexibility, innovation, and improvisation in their forms of expression.

Reed's formal experimentation-his imaginative interpretation of Voodoo and his development of a hybrid aesthetic that includes other forms of signification-reflects Voodoo's improvisational mode. During the novel's possession stage, for example, Reed intermingles geographies, literary allusions, and historical and cultural forms of knowledge, such as rumor and myth, while merging poetry with narrative, and drama with parody. ${ }^{21}$ His formal innovation demonstrates his desire to perform a metaphorical rather than a naively authentic interpretation of Voodoo's belief and practice. ${ }^{22}$ Indeed, Reed's use of Voodoo intentionally dispenses with the notion of authenticity in favor of an open, fluid approach that enables him to use and mix the different traditions available to him as an African American.

Reed thus configures specific aspects of Voodoo but also invents new forms of interpreting Voodoo's power. Guede, for example, who is not only associated with death and eroticism but also known as a "witty clown" and as a loa of history ("DH," 112), helps Reed to signify on the nuances of slavery's historiography and to satirize the ideological obsessions it has produced. In Guede's spirit, Reed exposes the interrelation between the dead and the living, between slavery and its legacy, and between material realities and discourses. The novel's short chapters begin with visual descriptions that, as Matthew Davis notes, suggest stage directions and announce the framing of images that will be mobilized by overblown action and satirical dialogue ("SHCT," 752-53). The opening of chapter 3, for example, de- 
picts the figure of the immoral and decadent Southern master, made familiar most poignantly by Stowe's Simon Legree:

The Master's study. Arthur Swille has just completed the pushups he does after his morning nourishment, two gallons of slave mothers' milk. Uncle Robin, his slave, is standing against the wall, arms folded. He is required to dress up as a Moorish slave to satisfy one of Swille's cravings. $(F C, 18)$

The scene recalls Stowe's characterization of the master class as obscenely decadent and idiosyncratic, but here and throughout, Reed aggrandizes these excessive qualities and hyperbolizes their grotesque nature. Reed conjures Swille to discursively "walk" within the novel as a sadomasochist in love with his set of whips, his opium, his dead sister Vivian, and the romance of an Arthurian South. Anachronistically, he is a corporate mogul whose money not only directs the course of the Civil War but also allows him to enact his private fantasies on a grand scale. Swille ravages the tomb of his dead sister while singing Poe's "Annabel Lee"; tries to buy a title ("Baron Swille ... Sir Baron Swille? . . Maybe the Marquis d'Swille"); and has Queen Victoria flogged for refusing to give him one $(F C, 109,127-28){ }^{23}$

What is fact and what is fiction in this exaggerated vision of mastery? ${ }^{24}$ Although Swille is quite obviously a farcical figure, he suggests real questions. How much, for example, does his image signify on a material reality of slavery in which the excessive power of masters could indeed be sadomasochistic? At the same time, while sexual licentiousness, miscegenation, and sexual oppression are painful parts of the history of slavery, how much are they also fetishistic images of the past? ${ }^{25}$ Reed evokes these questions in Flight to Canada through "a multifocal point of view" that, as Norman Harris argues, provides a kind of "epistemological democracy" that "challenges the reader both to determine whom to believe and to question what is real." 26 Throughout the novel, the reader consistently returns to these questions: What is fact and what is fiction in the "[s]trange" history of slavery? $(F C, 8)$. How are stereotypical notions both living and dead images of the past? How are they dynamically active forces of the here and now? In Voodoo, the dilemma would be posed this way: since Reed conjures both the zombies and ancestor spirits of slavery, how can the reader discern between the two?

By emphasizing the mysterious qualities of some characters while 
accenting the overbearing materiality and spiritual emptiness of others, Reed aids us in discerning between the loa and the zombies he conjures. As Davis notes, the minor character Pompey is known throughout Flight to Canada "simply as the slave who 'doesn't say much but is really fast." We know little else about him, adds Davis, "until the end of the novel when it is revealed that Pompey, through his ability to impersonate "the whole Swille family' . . . precipitates the demise of the Swille plantation.” As Davis observes, Pompey masquerades as Mistress Swille's dead son Mitchell-propelling her into madness - and impersonates Master Swille's sister, Vivian, causing Swille's death "when the spectra-like figure pushes him into the fireplace” ("SHCT," 752). "He's a good voice-thrower too," Robin tells us, suggesting Pompey's trickster powers $(F C, 175)$. In the end, we know little else except the fact that he is the figure who appears "from out of nowhere" to announce Raven's return from possession $(F C, 179)$. Meanwhile, to Swille, Pompey is merely a good "bargain" because he does “the work of ten niggers ... doesn't smoke, drink, cuss or wench, stays up in his room when he's not working, probably contemplating the Scriptures" $(F C, 35)$. Of course, it is not so simple to read Pompey.

Like Guede, Pompey's presence suffuses the novel as a force whose effect is radical but also not sharply defined. Does Pompey signify the indefatigable, creative, and amorphous power of resistance that made survival in slavery possible? According to Davis, Pompey is an allusion to William Wells Brown, who briefly appears in the novel to help Raven while he is on his way to Canada, and whose autobiographical persona in My Southern Home was also named Pompey (“SHCT," 751-52). If so, Reed's Pompey is an evocation of Brown, an actual historical ancestor of slavery, whose artistic legacy has provided Reed with a model for his own work. Reed's conjuring in this instance allows Brown's spirit to "walk" within the pages of his novel and to manifest itself in the novel's narrative present.

\section{“Don’t Choo Be Sistering Me"}

Reed reserves the realm of mystery for the loa of slavery, emphasizing their power by showing their ability to escape classification. By contrast, he conjures the power of slavery's stereotypes through satire, overexposing their grotesque and limited nature. Through the overblown language and action with which he characterizes them, Reed 
also stresses the violence that the "zombies" of slavery perpetuate. His blatant parody of the mammy figure, for example, reveals how stereotypes are both obviously fictive and strangely real, part of both the past and the present. On one hand, Mammy Barracuda is so clearly a stereotype that some have charged Reed with recirculating demeaning images of women under slavery. Although Reed has said that he "erred in giving her such an obvious name," I think it is precisely that obviousness that distinguishes her from the simple stereotype. ${ }^{27}$ By overdrawing Barracuda's purportedly privileged position as a trusted "house slave," Reed magnifies the distortions that the idea of mammy has produced. When she enters the novel, he depicts her as the caricature of a caricature: "Barracuda has a silk scarf tied about her head. A black velvet dress. She wears a diamond crucifix on her bosom. It's so heavy she walks with a stoop. Once she went into the fields and the sun reflected on her cross so, two slaves were blinded" $(F C, 20)$. For Norman Harris, this description shows Barracuda's darkly humorous but violent and "determined attempts to make life static and predictable" for others. As a stereotype, she not only preserves the status quo but also demands that others assume similar roles. Harris notes, for example, that when mistress Swille rebels against the role of the Southern belle, she "literally beats the woman back into the proper stereotype" just as harshly as she subjects the slaves under her power to perform their assigned roles. ${ }^{28}$ What Reed stresses about Barracuda is not her historical accuracy but her role as a historically produced icon whose effect is neither uniform nor unreal. Like the diamond crucifix she bears, Barracuda looms large and heavy in our imagination, blinding us to the possible realities of the women who were called slaves. $^{29}$

Reed's emphasis, furthermore, on Barracuda's material privilege suggests her commodity value as an ideological fiction..$^{30}$ There is something rich and alluring about evoking and circulating this character, Reed suggests, and something palpable in her effect. Reed creates this richness quite literally through the exaggerated language with which he represents Barracuda beating her mistress into the belle stereotype:

Barracuda enters the Mistress' room. Surveys the scene. Puts her hand on her hips. The Mistress flutters her eyes. Turns her head toward the door where Barracuda is standing, tapping her foot. 
"Oh, Barracuda, there you are, my dusky companion, my comrade in Sisterhood, my Ethiopian suffragette."

"Oooomph," Barracuda says. "Don't choo be sistering me, you lazy bourgeoise skunk."

"Barracuda,” Mistress says, raising up, "what's come over you?"

"What's come ovah me? What's come ovah you, you she-thing? Got a good man. A good man. A powerful good man. And here you is-you won't arrange flowers when his guests come. You won't take care of the menu. You won't do nothing that a belle is raised to do."

"But Barracuda, Ms. Stowe says. .." $(F C, 111)$

Barracuda so dramatically embodies the stereotype of the loyal slave that she praises the power of the man that keeps her enslaved. Her performance, however, amounts to a grotesque image of loyalty gone haywire. The interchange between her and mistress Swille, therefore, climaxes in a darkly humorous swirl of violence and slapstick. As Barracuda tries to force mistress Swille to perform her belle duties, she yells:

"Get out dat bed!"

"Why ... what? What's come over you, Barracuda?" Barracuda goes to the window and raises it. "This room needs to air out. Oooooomph. Whew!" Barracuda pinches her nose. "What kind of wimmen is you?"

"Why, I'm on strike, Barracuda. I refuse to budge from this bed till my husband treats me better than he treats the coloreds around here."

"Now, I'm gon tell you one mo time. Git out dat bed!"

"Barracuda! This has gone far enough." The Mistress brings back her frail alabaster arm as if to strike Barracuda. Barracuda grabs it and presses it against the bed. "Barracuda! Barracuda! You're hurting me. Oooooo."

Barracuda grabs her by the hair and yanks her to the floor.

"Barracuda, Barracuda, what on earth are you doing to my delicate frail body. Barracuda!"

Barracuda gives her a kind of football-punt kick to her naked hip, causing an immediate red welt.

Barracuda pulls her razor, bends down and puts it to Ms. Swille's lily-white neck. "You see that, don't you? You know what that is now? Now do what I say." 
"Anything you say, Barracuda," Ms. Swille says, sobbing softly.

"BANGALANG. BANGALLLLAAAANNNNG. YOUUUUUU. WHOOOOOO. BANGALANG." Barracuda, one black foot on Ms. Swille's chest, calls for her assistant. $(F C, 112)$

This scene's verbal and physical vortex recalls the raucous interchanges common to the antebellum minstrel stage, but the scene attains yet another level of signification in Reed's hybrid style. Replicating the sounds, exaggerated gestures, and pace of an animated cartoon, Reed mixes fantasy, fact, and fiction as he forces into collision the image of the "delicate frail" mistress and that of the boisterous "barracuda" mammy. Though together these figures create a maelstrom of action, they repeat the same gestures: Barracuda attacks (screaming, kicking, and yanking) while the mistress lamely protests (sobbing, as her "alabaster," "frail body" swoons). The scene thus creates the illusion that freeze frames of the same characters turn speedily before the reader's eyes in slightly different postures, stopping only when Bangalang is called in by Barracuda's obnoxious, though eerily hilarious, command. Bangalang, like the mistress and the mammy, is a caricature of a caricature: a stereotyped "pickaninny," whose familiar characteristics and gestures Reed reemphasizes. She "rushes into the room, her pickaninny curls rising up, her hands thrown out at the red palms, her eyes growing big in their sockets at the sight" of Barracuda beating mistress Swille $(F C, 112)$. Constituting the final freeze frame, Bangalang allows us to pause on the stereotype and examine its contradictions. It is as loud and obvious as Barracuda's language yet empty of consciousness; it is violent in its effects-witness Barracuda's brutality - and yet it is as naive as Bangalang and as infuriating as the seemingly innocent mistress.

While Reed shatters the rules of realism and verisimilitude, stressing instead the scene's cartoon-like qualities, he also shows that mistress Swille, Bangalang, and Barracuda exist as powerful fictions whose strange and complicated natures are at once historical and mythical. Reed in fact constructs the interchange between Barracuda and mistress Swille after an emblematic scene in David O. Selznick's film adaptation of Gone with the Wind (1939), where the Mammy of Margaret Mitchell's imagination laces Scarlett O'Hara's corset and helps her get dressed for a social gathering. As in Reed's novel, the film's mammy is a figure of mythic proportions: physically enormous, 
desexualized, and heavily racialized, she is determined to help her overly pampered and delicate mistress officiate her position as a belle. As Maria St. John shows, the film's scene plays upon this notion, showing Mammy as she forces Scarlett's tiny waist into the confines of an even smaller corset with a strength that so borders on violence that Scarlett must cling to her bedpost and, as Mammy tells her: " $[\mathrm{H}]$ old on and suck in." Mammy, whose own physical size attests to how fully she fills the roles assigned to her, worries that if Scarlett does not eat before the party she might be "eatin' like a field hand" and not like the proper lady she (Mammy) has worked so to hard to keep in line. ${ }^{31}$ In the same scene, Mammy and Scarlett have a veritable tug-of-war over Scarlett's bust line, a tug-of-war Reed recalls but parodies by having Barracuda literally beat mistress Swille.

In fact, Barracuda is so vociferous and demanding as the stereotype of race and gender she embodies that, in all respects, she outdoes the mammy of the screen. Reproducing the film's mammy-belle relationship but layering a cartoon-like style upon it, Reed emphasizes the looming but fictive nature of the mammy and, at the same time, leads us to ask why it is that we persist in recreating and recirculating it. St. Jones notes that ninety percent "of the North American population has seen [Selznick's] film," and sales of Margaret Mitchell's original 1936 novel "have been rivaled only by the Bible" ("IAF," 127 ). Nevertheless, as late as 1998, Technicolor rereleased a digitally remastered version of Selznick's film. Why? Is it because we yearn to see Mammy force Scarlett into her corset time and time again? As the recent debate over Alice Randall's The Wind Done Gone (2001) would suggest, Mitchell's text continues to stir something in us. What is it? What fantasies do slavery's stereotypes, especially as rendered by Mitchell, embody? Why must we continually rehearse them? The image of the mammy of slavery in particular, St. John suggests, exists as "a dominant cultural fantasy" that is "reenacted with each new production of her image"; she exists as a "fantasied fugitive who escapes no matter how many times she is captured on celluloid or in print" (“IAF," 127).

Reed's conjure also suggests that the mammy stereotype, like that of the Southern belle, works both as an index to the history of slavery and as a barrier against it. As such, its appeal rests in its power simultaneously to gesture to and obscure a difficult part of the national consciousness. As historical indexes, the mammy and belle stereo- 
types direct our attention to nineteenth-century ideologies of gender and alterity, specifically to the notion that white and black femininity mutually define and oppose one another. The battle that Reed stages between mistress and mammy not only dramatizes this point but also shows the violence necessary to uphold such a racialized notion of femininity.

But the battle also suggests that stereotypes of the mammy and the belle obscure the ways people in the nineteenth century questioned ideologies of race and gender. When mistress Swille calls Barracuda her "Ethiopian suffragette," she whimsically alludes to the connection drawn by women such as Elizabeth Cady and Lucretia Mott at the 1848 Seneca Falls convention between the disenfranchised status of women and that of enslaved people in the nineteenth-century United States. ${ }^{32}$ Although the experiences of slaves and white women (particularly those from the upper classes) differed drastically, suffragists stressed that women's status aligned them with the enslaved population of the country because, like slaves, women could not control their own persons or property, vote, choose a profession, or hold public office. While African American figures like Sojourner Truth, Harriet Jacobs, Frederick Douglass, and other abolitionists appealed to women's sympathies in hopes of enlisting them in their cause, suffragists used the rhetoric of slavery to awaken white women's consciousness. In Reed's text, however, the mistress and mammy are so consumed by the roles assigned to them that they cannot realize the promise implied by a union of the suffrage and abolitionist causes. Instead, mistress Swille lamely calls out to Barracuda from her lair of leisure while Barracuda violently rejects her ("Don't choo be sistering me, you lazy bourgeoise skunk").

Reed's satirical conjuring moves us to explore how, as expressions of perceived racial difference, stereotypes can become violently obsessive fantasies. Yet his conjure is complicated and potentially problematic since it also shows the allure that stereotypes exert across racial divisions. Stereotypes can be used as tools by the master class to manipulate and oppress the dispossessed. But as David Mikics argues, for Reed, stereotypes "may also stem from, or be appropriated by, African-American counterculture," thereby becoming tools of empowerment. ${ }^{33}$ Uncle Robin, for example, manipulates the stereotype of the faithful, child-like servant epitomized by Stowe's Uncle Tom in order to revolutionize the hierarchy of the Swille plantation. Swille, 
who suffers from dyslexia, comes to depend on Robin to care for his estate after his former secretary (Raven) escapes; Robin then uses the guise of the faithful servant to rewrite Swille's will so that upon Swille's death, Robin inherits the plantation and the right to free its slaves $(F C, 167-69)$. Once Swille dies - a death Pompey provokes but that would have occurred anyway since Robin has been surreptitiously poisoning the master's coffee for years-Robin frees Stray, 40s, and Raven and plans to transform the plantation into "something useful" for everyone $(F C, 179)$. "Yeah, they get down on me an Tom," Robin says, referring to Stowe's character, "[b] ut who's the fool?" $(F C, 178)$.

\section{Stereotype as Fetish, Conjure as Sabotage}

Through Robin, Reed shows that the dispossessed can manipulate stereotypes, turning them into weapons with which to destroy those who impose them. Through Barracuda and Stray Leechfield, however, he demonstrates that the oppressed can be seduced into perpetuating the dehumanizing impact of stereotypes. Stray, whose name insinuates his deviant (astray) and parasitic (Leechfield) characteristics, believes that the world the slavemasters have created inescapably revolves around money and depends on the marketing of everything, including people. Unlike Robin, Stray does not believe he can redefine the power relations that render him property, insisting instead that the only possibility left for him is to manipulate the rules of the market. "If anybody is going to buy and sell me" he tells Raven, "it's going to be me" $(F C, 73)$. Accordingly, he decides to purchase himself from Swille with the money he can earn in the pornography market by photographing himself and selling his image.

Stray's decision results from the illusion of mastery he creates by controlling the terms under which he is sold and from the monetary power he believes he garnishes. "I pull in more money in a day than you do in a whole year," he tells Raven. "You green, man. Brilliant but green" $(F C, 72)$. Raven, by contrast, will not accept his logic and vehemently argues against it. "We're not property," Raven tells Stray. "Why should we pay for ourselves?" $(F C, 74)$. Unwilling to heed Raven, Stray continues with his plan. Along with his partner, Mel Leer, he develops a scheme that imitates nineteenth-century minstrel shows. Leer, who is white, pretends to be Leechfield's owner, dresses him in the exaggeratedly perfect image of a runaway slave ("black 
cloth pantaloons, black cloth cap, plaided sack coat, cotton check shirt and brogans") and sells him, only to kidnap him back and "repeat the same routine to a different buyer the next day" $(F C, 80)$. But soon they develop a more abstract form of this scheme. Leer takes photos of Stray performing the duties of a slave and sells them in a mail-order business they call “'I'll Be Your Slave for One Day'” $(F C, 80)$. These photos feature Stray in compromising positions, as Raven finds out when he inadvertently walks into a session:

Oh my God! My God! My God! Leechfield was lying naked, his rustcolored body must have been greased, because it was glistening, and ... [a] naked New England girl was twisted about him, she had nothing on ... And then there was this huge bloodhound. He was licking, he was ... [Leer] was underneath one of those Brady boxes-it was flashing. He . . he was taking daguerreotypes, or "chemical pictures." $(F C, 71)$

The switch from the actual scheme toward its marketing through pornography elaborates Reed's connection between slavery as a market of bodies and the reification of its signs. At first, Leer and Leechfield restage the auction block as a profitable play act but then they discover that its pornographic image sells just as well, if not better. Certain icons of slavery, Reed suggests, have quite a profitable market. "You'd be surprised," 40s tells Raven, "how many people enjoy having a slave for a day even when they can't touch them" $(F C, 80)$.

Through Stray and Leer's pornographic daguerreotypes, Reed suggests that, as vessels for cultural fantasies, stereotypes can embody sexual fetishes. Stray exhibits himself (at least in the photograph Raven describes) performing one of the most potent and obsessive visions born out of slavery: a hyper-sexualized black man in a naked embrace with a white woman. This image, like those created by Mitchell and Selznick, has a sizeable market. It sells because it plays out a national taboo and thus satisfies a longing to see what has been historically prohibited. While black men have been killed for simply looking at white women, they have constantly been imagined as raping them. Like Leer's flash, Reed's satire overexposes the outrageous proportions this fantasy has attained, showing us Stray's body, greased and glistening, while the New England girl writhes around it. The image of the huge bloodhound (licking Stray?) succinctly suggests that lynching is the violent result of this fantasy, by alluding to the chase just before the horror of blood and burning flesh. 
Signifying on photography as a meaning-making medium, Reed uses the often imagined but impossible scenario of sex between black men and white women to suggest Stray's complicity in perpetuating a violent myth and promoting his own reification. He shows that while Stray believes he is purchasing his freedom through his scheme, he is in effect defining his own zombification. By choosing to sell himself through pornographic photographs, he quite literally turns himself into a material but spiritless image that replays a racial-sexual fantasy for somebody else's pleasure.

As Metz remarks, a photograph's signifiers seem bound to their referents through the image's contiguity with the world. Since mimetic photography retains the trace or index of actual living bodies and presents chemical images (or icons) that look like the objects the photographs represent, it creates a seductive illusionary pull. Spectators have a strange feeling of reality before a photograph, Metz argues, a desire to confound the signifier with the referent despite the fact that they know a photograph is only a representation. ${ }^{34}$ As photographs, the pictures that Leer takes of Stray suggest that there is no gap between reality and the cultural fantasy of rape and sex associated with black men. Stray becomes the thing itself: the fantasy writ large. What is more, because photographs are small enough to be carried, handled, and touched, Stray and Leer produce a sexual fantasy that can be literally marketed as a fetishistic object. To paraphrase 40s, people might actually "enjoy having [Stray as] slave for a day" precisely because they can touch and pocket him.

Through the novel's historical transposition of time, Reed draws out implicit connections between slavery as a market of bodies and its legacy in our contemporary world. When Raven and Stray argue over the question of purchasing themselves, they echo an actual dilemma that fugitive slaves faced in the nineteenth-century United States. Confronted with the difficult choice of purchasing freedom from their masters or remaining perpetually in flight, many fugitives "bought" themselves despite the implications of the gesture. In their slave narratives, Douglass, Jacobs, and Brown, among others, take up the nuances and difficulties of such a compromising position. Reed's Stray, by contrast, flaunts his decision and cynically argues that the act of buying oneself does not need to be as blatant as his own: "I don't see no difference between what I'm doing and what you're doing," he tells Raven $(F C, 72)$.

As Stray sees it, Raven, like Douglass and Brown, is an antislavery 
lecturer who also performs as a racialized being to market a consciously crafted image of himself. But whereas Stray's image brings in money, if not political power, Raven's brings insult. "You have to get evil-smelling eggs thrown at you," he tells Raven. Referring to events that actually occurred to Brown and Douglass, he continues: "I heard up at Buffalo they were gettin ready to throw some flour on Williams Wells Brown. Remember when those mobocrats beat up Douglass? Even Douglass, knocked on the ground like any old vagrant" $(F C, 72){ }^{35}$ In contrast, Stray is rewarded for playing out stereotypes of black masculinity. At the end of the novel, he appears "dressed in a white Russian drill coat, ruby-red plush breeches, a beautiful cloth waistcoat . . . a splendid silk shirt and a rakish French hat from New Orleans. ... rings on all of his fingers, a diamond stickpin on a cravat and Wellington boots" $(F C, 176)$. Like Barracuda, Stray is bedecked with items that, in their richness and materiality, suggest the commodity value he has as an ideological fiction. Reed implies that the fantasy of the black stud-rapist continues to seduce our imagination and that this seduction cuts across racial divisions. Exploiting his use of outlandish anachronisms, Reed presents Stray as a version of a contemporary "pimp daddy." As Swille tells us earlier in the novel, "the glistening rust-black Stray Leechfield" stole from him so methodically that at one point he became "big" enough to be seen "over in the other country, .... dressed up like a gentleman, smoking a seegar and driving a carriage which featured factory climate-control air conditioning, vinyl top, AM/FM stereo radio, full leather interior, power-lock doors, six-way power seat, power windows, white-wall wheels, dooredge guards, bumper impact strips, rear defroster and soft-ray glass" $(F C, 36)$. His "carriage," like a pimp's car, is "full of beautiful women fanning themselves and filling the rose-tinted air with their gay laughter" $(F C, 36)$. Reed's hilarious conjuring of Stray as a fugitive slave turned minstrel-porn-star-pimp allows us to examine a potent and persistent stereotype in all its details. Like the carriage-pimp car Reed describes so carefully, Stray is an elaborate cultural fantasy, richly manufactured and infinitely marketable.

As a novelist, however, Reed is primarily concerned with how people are reified through words. In Flight to Canada, therefore, he presents us with a case of narrative zombification and enacts an imaginative sabotage against it. In the novel's first section, "Naughty Harriet," Reed humorously reiterates the charge commonly made 
against Stowe when she published Uncle Tom's Cabin that she took her book's plot from the slave narrator Josiah Henson. In Reed's text, Harriet is "naughty" not only because she "stole" but also because she is said to have been inspired to write her novel by a petty desire ("Harriet only wanted enough money to buy a silk dress" [FC, 8]). Strikingly, Reed suggests that Stowe's intentions and theft have something to do with "pornography" $(F C, 8){ }^{36}$

According to Richard Walsh, Reed "freely acknowledges that his charge of plagiarism against Stowe is a tongue-in-cheek abuse of the scant evidence" behind Henson's rumored reputation as the real Uncle Tom. "I was having fun with Harriet Beecher Stowe," Reed tells Walsh, "saying that she took her plot in Uncle Tom's Cabin from Josiah Henson. You know, they did meet when she was four. . ." ${ }^{37}$ But the fiction provides Reed with a paradigm for exploring the debateencapsulated in James Baldwin's well-known reading of Uncle Tom's Cabin-surrounding Stowe's discursive reification of African Americans. Baldwin praises Stowe for passionately critiquing the institution of slavery but derides her for declining to examine the internal and subjective experiences of the people who were enslaved. Stowe's novel became not only a bestseller but also the standard that shaped the subsequent production and reception of slave narratives and influenced the development of African American literature more generally. For Baldwin, however, Stowe's novel simultaneously established a paradigm for understanding slavery and represented those who were enslaved, without including their own stories. In his estimation, Stowe used slaves as signs to serve her own goals. ${ }^{38}$

Using the rumor regarding Stowe's theft of Henson's story, Reed correlates zombification with the reification of people through language. Henson, Reed suggests, is enslaved physically and reenslaved discursively when Stowe usurps his story, renames him Uncle Tom, and finally resells him on the literary market for her own economic profit and literary posterity. Stowe thus prostitutes Henson's story in a manner remarkably close to Leer's pornographic selling of Stray's body ${ }^{39}$ For Reed, discursive zombification occurs when people's stories are taken from their bodies, co-opted, and transformed to suit purposes other than those of the person to whom the story belongs. And what happens to those whose stories are stolen? According to Raven, "People pine away. It baffles the doctors the way some people pine away for no reason. For no reason? Somebody has made 
off with their Etheric Double, has crept into the hideout of themselves and taken all they found there. Human hosts walk the streets of the cities, their eyes hollow, the spirit gone out of them. Somebody has taken their story" $(F C, 8)$. What Raven refers to as a person's "Etheric Double" is also what he calls a person's "gris-gris," the "thing that is himself," and what in Voodoo is known as one's "gros bon ange" $(F C, 8)$. Voodoo practitioners in Haiti, notes Dayan, see individual identity as comprising three parts: the petit bon ange (a person's consciousness and affect), the gros bon ange ("the double of the material body-something like our idea of spiritus"), and the corps cadavre (or physical body). The gros bon ange can easily detach itself from the body and be "seized" by a sorcerer, never to return ("V," 51). For Reed, our stories are synonymous with our gros bon ange: they are the double of our material body; they are our shadows. As Keith Byerman puts it, "[N]arrative [in Flight to Canada] is the self, the ordering of identity that gives body and voice through language." ${ }^{40}$ Words are our gris-gris or the charms that protect our shadows from co-optation. But sometimes words fail, and our stories are taken from us.

In the spirit of Guede, who is the loa that has the power to "animate the dead as zombies" and to heal and protect against the possibility of being turned into one, Reed stages a case wherein the enslaved is saved from being discursively reified by the powers of conjure ("DH," 113). Along with Raven's introduction-incantation, the novel begins with a key proposition: Robin asks Raven to write his life story. Given the example of Henson's narrative dispossession, Raven is to make sure he writes Robin's story in a way that prevents anyone from stealing it. "Now you be careful with my story," Robin tells him, requesting that he "put witchery on the word" $(F C, 13)$. This demand is, in fact, a localized case of Reed's own novelistic crux: the challenge of conjuring rather than zombifying the subjects of slavery. Raven, like Reed, must conjure Robin's story, and by extension, that of slavery, as a living text (even the alliteration of their names suggests their common purpose). Both Raven and Reed cannot, as Baldwin claimed Stowe did, present slavery through a litany of discursive characters and acts that repeat petrified images of people. Instead, Robin's story must be like Reed's maverick novel itself and call into being the ancestor spirits of the past.

At its close, the novel returns to the Stowe-Henson rumor to emphasize, finally and clearly, its difference from Stowe's narrative produc- 
tion. Robin, who delivers the novel's last reflective words, has not been zombified by the narrative. Thus, when Stowe reenters the novel to ask Robin if she can "do a book" on him, Robin promptly tells her that he already has an author $(F C, 174)$. He will not be reified. Circling back to its beginning, the novel leaves us as Raven returns to write Robin's story, a story that in the end is the account of slavery we hold in our hands.

Reed's formal innovation is thus crucial to the project against discursive zombification. It is also an element that sets his work apart from other contemporary representations of slavery. Although Flight to Canada, like other texts classified under the generic categorization of the neo-slave narrative, does signify on the form and conventions of the antebellum slave narrative, it is not limited to that enterprise. It is driven by Reed's imaginative combination of Voodoo and postmodern aesthetics, which allows him to provide what Ralph Ellison, after Kenneth Burke, called "perspective by incongruity." ${ }^{41}$ It allows him to show the underpinnings of the U.S. racial mythology by returning us to the overtly familiar, overdetermined stereotypes of slavery with a grammar that gives way to concepts that might, at first glance, seem esoteric (such as discursive zombies) but that, through their uniqueness, serve to expose ideological fetishes at the heart of American history and literature. Reed, like a number of other contemporary writers who focus their attention on New World slavery, experiments with form to explore not only the disturbing contradictions in the discourse of slavery but also the ways in which such a discourse continues to shape our own language and the practice of our everyday lives. ${ }^{42}$

Harvard University

\section{Notes}

I would like to thank my mentor and friend, Samuel Otter, for reading early drafts of this essay and for his wise and kind encouragement.

1 At the end of his groundbreaking 1993 study, Paul Gilroy discusses a few late-twentieth-century novels centered on the epistemological and hermeneutical dilemmas that the history of New World slavery presents (see The Black Atlantic: Modernity and Double Consciousness [Cambridge: Harvard Univ. Press, 1993]). But Gilroy's list can be significantly extended. Among the first texts of the mid-1960s and early 1970s to focus on slavery 
are Margaret Walker's Jubilee (1966), Ernest J. Gaines's The Autobiography of Miss Jane Pittman (1971), and Gayl Jones's Corregidora (1975). These works were followed by Ishmael Reed's Flight to Canada (1976), Alex Haley's Roots (1976), Octavia Butler's Kindred (1979), Charles Johnson's Oxherding Tale (1982) and Middle Passage (1990), and J. California Cooper's Family (1991) and In Search of Satisfaction (1994). Similar texts include Caryl Phillips's Higher Ground (1989), Cambridge (1991), and Crossing the River (1993); Derek Walcott's epic poem, Omeros (1990); Kamau Brathwaite's three-part epic The Arrivants (1992); Barbara ChaseRiboud's The President's Daughter (1994); and Fred D'Aguiar's The Longest Memory (1994). Most notable among the attempts before the midsixties to represent the history of slavery from a twentieth-century perspective is Robert Hayden's “Middle Passage” (1944), a poem that highlights the internal sites of tension that characterize historical documentary while underscoring the connections between the religious, commercial, and legal language of the slave trade. For a discussion of factors contributing to the emergence of these fictional narratives, see Ashraf H. A. Rushdy, Neo-slave Narratives: Studies in the Social Logic of a Literary Form (New York: Oxford Univ. Press, 1999), 3-22.

2 Bernard W. Bell coined the term "neo-slave narrative" to describe "residually oral, modern narratives of escape from bondage to freedom" (The Afro-American Novel and Its Tradition [Amherst: Univ. of Massachusetts Press, 1987], 289). Rushdy defines neo-slave narratives as "contemporary novels that assume the form, adopt the conventions, and take on the firstperson voice of the antebellum slave narrative" (Neo-slave Narratives, 3 ).

3 Rushdy has shown the extent to which Reed, in Flight to Canada, corrects not only historical texts on slavery but also fictional works, such as Harriet Beecher Stowe's Uncle Tom's Cabin (1852) and William Styron's The Confessions of Nat Turner (1968). While thorough and compelling, Rushdy's discussion of Flight to Canada overstresses Reed's desire to revise slavery's record (Neo-slave Narratives; see, in particular, 99-110). Reed does more than simply rewrite master texts. For an example of criticism in Rushdy's revisionist vein, see Elizabeth Ann Beaulieu, Black Women Writers and the American Neo-slave Narrative: Femininity Unfettered (Westport, Conn.: Greenwood, 1999). Beaulieu shows how fiction can be used to "reinscribe history from the point of view of the black woman" (2). Toni Morrison, on the other hand, is more concerned with imaginatively filling in the omissions in slave narratives and autobiographies, especially the "interior life" of the people who were enslaved; see her "The Site of Memory," in Inventing the Truth: The Art and Craft of Memoir, ed. Russell Baker and William Zinsser (Boston: Houghton Mifflin, 1995), 91.

4 See Milo Rigaud, Secrets of Voodoo, trans. Robert B. Cross (1969; reprint, San Francisco: City Lights, 1985), 8. 
5 Reed acknowledges William Wells Brown and Charles Chesnutt as his literary predecessors who transfigured "conjure" into narrative form (Ishmael Reed, interview by the author, 14 June 1999). For a discussion of Brown's influence on Reed, see Matthew R. Davis, “'Strange, History. Complicated, Too': Ishmael Reed's Use of African-American History in Flight to Canada," Mississippi Quarterly 49 (fall 1996): 744. Further references will be cited parenthetically as "SHCT." For a discussion of Chesnutt's use of conjure as a literary trope, see Eric Sundquist, To Wake the Nations: Race in the Making of American Literature (Cambridge: Harvard Univ. Press, 1993), 359-92.

6 Houston A. Baker Jr. has evocatively referred to "critical memory" as a mode of remembrance that refuses nostalgia and other unproblematized forms of recollection to focus on the relationship between the past and "the always uprooted homelessness of now" ("Critical Memory and the Black Public Sphere,” Public Culture 7, no. 1 [1994]: 3).

7 See Maya Deren, Divine Horsemen: The Living Gods of Haiti (1953; reprint, New Paltz, N.Y.: McPherson, 1983), 76; further references will be cited parenthetically in the text as "DH."

8 Joan Dayan, "Vodoun, or the Voice of the Gods," Raritan 10 (winter 1991): 40; further references will be cited parenthetically as "V."

9 Dayan asserts that "the division between houngan and boco . . . is not so absolute. In the north of Haiti boco means houngan." The houngan who is dedicated to his community, however, avoids misusing his powers ("Vodoun," 49).

10 See Jean Rhys, Wide Sargasso Sea (London: Andre Deutsch, 1996), 107; quoted in Dayan, "Vodoun," 54. Edward Rochester, from Charlotte Brontë's Jane Eyre, is not named, but all evidence points to him as the speaker.

11 According to Deren, a zombie is "[a] soulless body.... [whose soul] may have been removed by magic from a living person, or the body of someone recently deceased ... brought up out of the grave after the soul [has] been separated from it by regular rites of death." She notes that " $[t]$ he purpose is to make use of the body as a slave" (Divine Horsemen, 338, my emphasis).

12 The phrase "fantastic process of reification" comes from René Depestre, the Haitian novelist and poet; see Dayan, "Vodoun," 54.

13 Reed's dual performance as houngan and boco is actually in keeping with Voodoo practices. As Dayan notes, "[T]he houngan must be familiar with magic in order to fight against the machinations of sorcerers" ("Vodoun," 49).

14 See Rigaud, Secrets of Voodoo, 11.

15 Sämi Ludwig, "Dialogic Possession in Ishmael Reed's Mumbo Jumbo: Bakhtin, Voodoo, and the Materiality of Multicultural Discourse," in The Black Columbiad: Defining Moments in African American Literature and 
Culture, ed. Werner Sollors and Maria Diedrich (Cambridge: Harvard Univ. Press, 1994), 330.

16 See Helen Lock, “'A Man’s Story Is His Gris-Gris’: Ishmael Reed’s NeoHooDoo Aesthetic and the African-American Tradition," South Central Review 10 (spring 1993): 67-68.

17 Christian Metz, "Photography and Fetish," October 34 (autumn 1985): 86.

18 Ishmael Reed, Flight to Canada (1976; reprint, New York: Simon and Schuster, 1998); further references are to this edition and will be cited parenthetically in the text as $F C$.

19 Ashraf H. A. Rushdy, "Ishmael Reed's Neo-HooDoo Slave Narrative," Narrative 2 (May 1994): 132.

20 Deren's spelling of this Voodoo loa is "Ghede" (Divine Horsemen, 10214). Reed's different spelling reflects not only his improvisatory use of Voodoo but also the fact that the orthography of Voodoo sometimes varies because Haitian orthography generally bears the marks of different, sometimes opposing, colonial ideologies (see Joan Dayan, "Notes on Orthography," Haiti, History, and the Gods [Berkeley and Los Angeles: Univ. of California Press, 1995], xxiii).

21 For more on Reed's juxtaposition of references to antebellum figures (such as Harriet Beecher Stowe, Edgar Allan Poe, and Abraham Lincoln) and allusions to twentieth-century figures like T. S. Eliot as well as Ezra Pound and phenomena like the "top forty, the best seller list and the Academy Awards” (FC, 150), see Richard Walsh, “'A Man's Story Is His Gris-Gris': Cultural Slavery, Literary Emancipation, and Ishmael Reed's Flight to Canada," Journal of American Studies 27 (April 1993): 5771. By bombarding readers with an intricate mix of characters, places, and genres, Reed keeps them alert to the process by which he reconstructs slavery, thus foreclosing the possibility of a passive reading of the history he represents. Reed also keeps his reader attuned to the nuances of the texts he signifies on and to the cultural fields from which he draws them. His research for Flight to Canada extended beyond rereading slave narratives to examining texts by Confederate apologists, reconsidering Uncle Tom's Cabin (seeing both its limitations and the "heart" in it) as well as listening to "common" people and the stories they tell about slavery (Ishmael Reed, interview by the author, 14 June 1999). Because historical consciousness, for Reed, is partly to be found in what he calls the "lowdown and funky and homespun" of everyday reality, he also mined fields of popular culture such as "jazz, talk radio formats . . . television" and everyday dialogue. Flight to Canada, he claims, includes "overheard conversations"; "Interview with Ishmael Reed (1976)," by Stanley Crouch, in Conversations with Ishmael Reed, ed. Bruce Dick and Amritjit Singh (Jackson: Univ. Press of Mississippi, 1995), 96. Transforming his research into novelistic discourse, Reed points to those corners of slavery's archive that resist definition, opening the realms of historical possibility. 
22 See David Mikics, "Postmodernism, Ethnicity, and Underground Revisionism in Ishmael Reed," Postmodern Culture 1 (May 1991): paragraph 16 (April 2005); available on www.jstor.org. Mikics argues that Reed operates through an "aesthetic of 'sampling,' of inventively assembling snippets" of multiple traditions (paragraph 12). Reed calls his "sampling” of Voodoo and other traditions "Neo-HooDoo"; see, for example, his first book of poetry, Conjure; Selected Poems, 1963-1970 (Amherst: Univ. of Massachusetts Press, 1972), especially “Neo-HooDoo Manifesto,” 2025. For a discussion of Neo-HooDoo, see Rushdy, "Ishmael Reed's NeoHooDoo," 113-14.

23 Reed suggests that Swille, like the Napoleon III depicted in Karl Marx's The Eighteenth Burmaire of Louis Napoleon, makes a travesty of power in the name of a reactionary obsession with nobility. Sitting at a desk "rumored to have been owned" by his "good friend Imperial Majesty Napoleon Bonaparte III," Swille expounds on the pleasures of his Southern dream $(F C, 23-24)$. The American master, Reed implies, could use the power of capital to buy second-hand remnants of Europe's decaying signs of monarchical power. For an analysis of Reed's allusion to Edgar Allan Poe in this passage, see Joe Weixlmann, "Ishmael Reed's Raven," Review of Contemporary Fiction 4 (summer 1984): 205-8.

24 The question echoes Raven, who in his historiographic meditation asks: "Where does fact begin and fiction leave off?" in the "[s]trange" and "[c]omplicated" history of slavery $(F C, 10,8)$.

25 For a discussion of how the sexual licentiousness of slavemasters fueled fears and solidified the need to abolish slavery, see Ronald Walters, "The Erotic South: Civilization and Sexuality in American Abolitionism," American Quarterly 25 (May 1973): 177-201.

26 Norman Harris, “The Gods Must Be Angry: Flight to Canada as Political History,” Modern Fiction Studies 34 (spring 1998): 114.

27 Ishmael Reed, interview by the author, 14 June 1999. As Reed told me in conversation, Alice Walker wanted "to ban [his] books" based on her reaction to Barracuda. For a discussion of Reed and misogyny, see Trudier Harris, Saints, Sinners, Saviors: Strong Black Women in African American Literature (New York: Palgrave Macmillan, 2001); and Sondra A. O’Neale, "Ishmael Reed's Fitful Flight to Canada: Liberation for Some, Good Reading for All," Callaloo 4 (October 1978): 174-77. See also Peter Nazareth, "Heading Them Off at the Pass: The Fiction of Ishmael Reed," Review of Contemporary Fiction 4 (summer 1984): 208-26.

28 Harris, "The Gods Must Be Angry," 118.

29 For a discussion of Barracuda's crucifix and its blinding powers, see Hortense Spillers, "Changing the Letter: The Yokes, the Jokes of Discourse or, Mrs. Stowe, Mr. Reed," in Slavery and the Literary Imagination, ed. Deborah McDowell and Arnold Rampersad (Baltimore: Johns Hopkins Univ. Press, 1989), 31. 
30 For an exploration of the visual and literary birth and commodification of the mammy stereotype, see Jo-Ann Morgan, "Mammy the Huckster: Selling the Old South for the New Century,” American Art 9 (spring 1995): 87-109.

31 David O. Selznick, Gone with the Wind (1939; remastered, MGM Home Entertainment, 1998), quoted in Maria St. John, “'It Ain’t Fittin': Cinematic and Fantasmatic Contours of Mammy in Gone with the Wind and Beyond," Qui Parle 11 (fall-winter 1999): 134; further references will be cited parenthetically in the text as "IAF."

32 Elizabeth Cady Stanton and Lucretia Mott were inspired to organize the gathering at Seneca Falls in July 1848, commonly known as the first women's rights convention in the United States, after they accompanied their husbands to the 1840 World Anti-Slavery Convention in London and were required to sit behind a partition with all the other women who attended. Frederick Douglass, who participated at Seneca Falls, wrote a favorable review of the convention in his newspaper The North Star, while every other newspaper derided it; see Kathryn Cullen-DuPont, "Seneca Falls Convention," Encyclopedia of Women's History in America, 2nd ed. (New York: Facts on File, 2000), 232.

33 Mikics, "Postmodernism," paragraph 12.

34 See Metz, "Photography and Fetish," 82, 87.

35 Davis notes that when they were anti-slavery lecturers, Brown had flour thrown on him and Douglass was beaten; see "'Strange, History. Complicated, Too,'” 747.

36 Reed suggests that Stowe's charge of pornography against Lord Byron revealed her prurient interest in it and aligns this “naughtiness" with her purported stealing of Henson's story, since Stowe's co-optation of Henson for economic profit suggests a sort of prostitution.

37 Reed, quoted in Walsh, “'A Man's Story Is His Gris-Gris,” 66. For further discussion of this rumor, see Klaus Benesch, "From a Thing into an I Am," in Historiographic Metafiction in Modern American and Canadian Literature, ed. Bernd Engler and Kurt Müller (Paderborn, Germany: Schöningh, 1994), 257.

38 See James Baldwin, “Everybody's Protest Novel,” in Notes of a Native Son (1955; reprint, Boston: Beacon Press, 1984), 13-23.

39 Reed suggests that novelists like Stowe work more as bocos or magicians that conjure for profit rather than for healing or insight. Taking Stowe's claim that she "was an instrument of the Lord" when she wrote Uncle Tom's Cabin, Reed writes: "Harriet saying that God wrote Uncle Tom's Cabin. Which God? Some gods will mount any horse" $(F C, 10,11)$. Here Reed refers to the boco's magic that can seduce certain loa for material rather than spiritual purposes.

40 Keith Byerman, Fingering the Jagged Grain: Tradition and Form in Re- 
cent Black Fiction (Athens: Univ. of Georgia Press, 1985), 233; quoted in Rushdy, “Neo-HooDoo,” 121.

41 Ralph Ellison, Going to the Territory (New York: Random House, 1986), 193-94.

42 In this respect, Reed's work bears similarities to Gayl Jones's experiments in Corregidora (1975) with the form of the novel and the tradition of the blues in order to provide a feminist critique of slavery's sexual history. Transliterating the structure and rhythm of the blues, Jones also shows how that history affects relations between men and women now. Similarly, Octavia Butler experiments with modes of science fiction in her novel Kindred (1979) to create a bridge between the nineteenth and twentieth centuries and to show how slavery's past affects an interracial romantic relationship in the present. Reed's work prefigures narratives produced more recently and influenced by postcolonial and poststructuralist thought and practice. Caryl Phillips's novel Cambridge (1991), for example, is invested both in signifying on the archive of slavery and in examining our present concerns with representation and interpretation. Like Reed, Phillips is not concerned with attaining exact historical accuracy (even though the novel is situated in a West Indian sugar plantation sometime in the eighteenth century); rather, Phillips focuses on critiquing the literary conventions of a set of historical texts that produced a certain definition of the subaltern. He does not provide a retrospective account of the past but mixes direct historical allusions with subtle anachronisms and engages with debates regarding the instability of language and the critique of logocentrism. 